\title{
Absenting the Absence of Future Dangers and Structural Transformations in Securitization Theory
}

\section{Patomäki, Heikki}

2014-10-21

Patomäki , H 2014 , ' Absenting the Absence of Future Dangers and Structural

Transformations in Securitization Theory ' , International Relations, vol. 29 , no. 1 , pp.

128-136 . https://doi.org/10.1177/0047117814526606e

http://hdl.handle.net/10138/233389

https://doi.org/10.1177/0047117814526606e

acceptedVersion

Downloaded from Helda, University of Helsinki institutional repository.

This is an electronic reprint of the original article.

This reprint may differ from the original in pagination and typographic detail.

Please cite the original version. 
This is a post-peer-review, pre-copyedit version of an article published in International Relations, vol. 29, issue 1 . The final authenticated version is available online at: https://doi.org/10.1177/0047117814526606e.

\title{
Absenting the absence of future dangers and structural transformations in securitization theory
}

\author{
Heikki Patomäki
}

\section{Introduction}

The basic idea of securitization theory (ST) is that actors can bring about securitization by presenting something as an existential threat and by dramatising an issue as having absolute or very strong priority. ${ }^{1}$ There are two main readings of ST. To some extent they stem from two opposing views of what a theory (of securitization) can and should do; but they also reflect metatheoretical differences, being united only in their ambivalence about the possibility of anticipating the future in a meaningful and rational way. ${ }^{2}$ The first, usually associated with poststructuralism, focuses on language and more specifically on the speech act of securitization and its constitutive effects. ${ }^{3}$ The dramatic effect of the poststructuralist ST lies in the implicit denial of the reality of threats.

The second, more conventionally sociological approach analyzes the social process of securitization in terms of facilitating conditions, authority of the speaker and the complex social field within which securitization occurs. This approach does not deny that threats and dangers can be real, but its critical intent focuses on showing the impact of social conditions and relations that may distort, or even generate ex nihilo, representations of external dangers and threats. ${ }^{4}$

In this paper, I try to go beyond these approaches by absenting the absences in ST, namely the future as something that is real but not yet (fully) determined and (ii) the possibility of structural transformations. True, there is a sense in which the future and future threats are present in the post-structuralist version of the theory. Future dangers understood through the modern probability calculus are seen as constitutive of security-talk. Reality is socially constructed. While probability and claims about the future are may in this way be seen as real in constituting present practices, key works such as Barry Buzan's, Ole Wæver's and Jaap De Wilde's Security: A New Framework for Analysis are open to different readings on the question whether future dangers, threats and risks can themselves be real. ${ }^{5}$

The main argument in favour of relativism about security claims is that future security problems can only be meaningfully discussed if precise scientific predictions are possible. Predictions presuppose a closed, mechanical, and deterministic system. There are passages in Security: A New Framework and other works, however, that seem closer to traditional forms of materialist political realism, implying that threats and future possibilities can be real and foreseeable. ${ }^{6}$ But because of this 
ambivalence, only little work has been done in thematising future dangers as something real in themselves, not to speak of assessing their likelihood.

Similarly, structural transformations do play a limited role in securitization theory. Especially the sociological perspective can illuminate the possible effects of institutional changes, but it tends to direct attention to domestic structures only. Whenever ST takes into account and thematises the interactions of securitizing states, it resembles the "crude realist thinking about the balance of power, where the national security concerns of states $A, B, C, D$, etc. interact with each other on the basis of materialist calculations of threat" $"$. ST tends to assume a given structural setting and is interested only in the dynamics of interactions within this setting.

In some formulations, it allows for regional integration processes to make a difference by creating conditions for a pluralist security community, but mostly ST focuses on interactions among states in a states-system, understood in terms of political realism and British institutionalism. In contrast, in this paper I argue that real future dangers can be absented by transforming structures, including global political economy structures. This presupposes we can plausibly analyze possible and likely futures also in open-systemic, non-mechanical and non-deterministic contexts.

\section{Modern probability calculus as constitutive of the concept of security}

As a social mechanism, securitization is characterized by a fairly mechanical pattern between security-talk and particular kinds of responses to it. One can express this basic pattern of securitization by means of a simple if-then sentence: if $\{a, b, c\}$...., then securitization happens, and with it the defined effects $\{x, y, z\}$, typically involving some exceptional measures. ${ }^{8}$ In other words, security talk is triggered by something, and once triggered by this something, it brings about certain dedemocratising or militarising effects in a rather mechanical fashion.

The sociological approach insists that securitization requires a complex setting of social relations to work. However, also the sociological approach must assume that the use of the word "security" has potential to generate the defined effects, even though mere speech-act by someone somewhere is not sufficient for securitization to occur. Where does the power of security-talk come from?

A conception of security as oriented towards future dangers emerged with the European modernity. ${ }^{9}$ While collective violence has been a problem across the world, and while questions about military dangers and opportunities have been pondered and debated at least since the first millennium BC, security could not have been defined in terms of risks of future contingencies before the emergence of the concept of mathematical probability. ${ }^{10}$ Gradually, the concept of security became prominent in three apparently disconnected fields. The first is that of "social security". All people have faced the uncertainties brought on by illness, disability, 
maternity, death and old age, as well as by other eventualities such as bad weather. Since the late $19^{\text {th }}$ century, pushed by the rise of the labour movement and its demands, states have developed policies against these and more modern uncertainties such as unemployment, typically in terms of social insurances (by this time, private insurances were already a large-scale industry). Secondly, in the US Securities Exchange Act of 1934, "securities" were defined as any transaction that involves an investment of money in an enterprise, directly or indirectly, with an expectation of future profits - implying, however, a risk of loss - to be earned through the efforts of someone other than the investor. Thirdly, the concept of "national security" emerged as the official guiding principle of foreign policy in the US when President Harry S. Truman signed the National Security Act on 26 July 1947.

The theory of securitization presupposes these $20^{\text {th }}$ century meanings connected with the word "security", constituted by the modern probability calculus and concept of risk that can be traced back to the $17^{\text {th }}$ century. According to lan Hacking, the modern concept of probability that emerged in the 1660s had a dual meaning: it had to do with both a degree of belief and stable frequencies. ${ }^{11}$ The former, comes close to meaning "approvable as a basis for action", whereas the latter entails theories about calculating likelihoods, as well as testing hypotheses, in terms of infinite sequences of occurrences of something. The latter presupposes stable frequencies, in turn closely associated with the Humean regularity view of causation.

Risk can be defined in terms of probability $(\mathrm{P})$ and the value of loss $(\mathrm{VL})$ : risk $R=\mathrm{P} x$ VL. Modern security is about avoiding risks, concerning explicitly the future. A future loss can be imagined and then a probability attached to it. Given the $20^{\text {th }}$ century practices of insurance, securities exchange, and national security, a claim about potential future loss, misfortune or catastrophe is framed as a risk, which in the context of national (state, homeland) security has regularly generated dedemocratising or militarising responses. Logically, however, an attempt at securitization must be based on two claims, concerning (i) a danger that lies in the future and which may materialize with probability $p$ and (ii) the best way to respond to that danger. But how do we know whether claim (i) is true? Moreover, from a normative point of view, there is no automatic link from (i) to any particular (ii).

Ontologically, the future is real but not yet (fully) determined. Future is an increasingly shaped and structured possibility of becoming, mediated by the presence of the past. As Roy Bhaskar maintains, "the future is paradigmatically shaped possibility of becoming" that, as a possibility, "may be closer or more distant from us, more or less about, and more or less likely to be actualized" ${ }^{12}$. The question for critical security studies is: how can we assess claims about the future, which, reflexively, involve also likely consequences of one's own actions?

Action is always future-oriented and requires some knowledge about likely consequences. The concept of probability is thus indispensable for comparing anticipations in terms of whether they can provide an approvable as a basis for 
action. It is, however, possible to redefine probability in a way that detaches it from those modern cognitive and social forms, which have been intertwined with particular forms of mathematics (system of numbers, arithmetic, algebra and probability calculus) and practices and institutions of capitalist market society.

Importantly, John Maynard Keynes in his Treatise on Probability revived the older, practical meaning of the term probability. ${ }^{13}$ Keynes' theory was a synthesis between the belief and frequencies approaches, stemming from an attempt to find a basis for ethical actions. For Keynes, relative frequencies are only a type of relevant evidence and in many situations, they are not available. Probabilities are not necessarily numerical and sometimes cannot even be compared. Probability concerns an inference from evidence/reasons to our probability-judgements. The weight of evidence does not necessarily change our probability-estimate but may alter our confidence in it. Learning more about the situation can mean that our ignorance increases, implying that the weight of evidence and confidence may in fact decrease. ${ }^{14}$ Probability-judgements are thus necessarily complex and multi-layered.

To this Keynesian theory may be added a dialogical understanding about assessing probability judgements. Different actors, although all perfectly reasonable and having the same evidence $e$, may yet have different degrees of belief in $p .{ }^{15}$ The disagreement is not the end of the story, however. The problem of assigning different degrees of belief in, or having different probability estimates of, $p$ can become a topic in a rational cognitive controversy that follows the dialectical logic of formal disputations. ${ }^{16}$ Each dialectical step may also involve further research into the matter, accommodating new pieces of evidence and new geo-historical experiences. Furthermore, although the majority of relevant probabilities in historical social sciences may be non-numerical, we can nonetheless use the basic Bayesian theorem as a heuristic tool to assess the reasonable impact of an occurrence of new evidence or historical turns, i.e. to analyze how we should change estimates and beliefs. ${ }^{17}$

The point is that the likelihood of different possible futures can be assessed rationally. Therefore it may be quite sensible to present something as an existential threat or even dramatize an issue as having a strong priority. And yet, often these kinds of claims are exaggerated, unfounded or misleading. The scenarios may not be plausible or there is over-confidence in one's probability judgement, given the openness of social systems, nature of available evidence, and our degree of ignorance. Since world history unfolds in relatively open systems and is often sensitive to small changes in some conditions, anticipations of possible futures are contingent on a number of uncertain things: multifarious geo-historical processes and mechanisms (including homeostatic causal loops), and the modes of responsiveness of actors, which are linked to layered systems of collective learning and self-regulation. ${ }^{18}$ Through modes of responsiveness and mechanisms of learning, actors' expectations and anticipations are in fact an essential part of geohistorical processes. Scenarios may, and often do, lack critical self-reflexivity, even though prophecies can be self-fulfilling or self-denying - sometimes on purpose. ${ }^{19}$ 
Reflecting upon these uncertainties, feedback loops and relative openness of the future, the construction of scenarios about possible futures has also a moral aspect. Furthermore, even when a particular future danger is not only real but also likely, it is not evident what the best way to respond to that danger is. The choice of adequate response is an ethico-political question par excellence. Hence, instead of merely describing a quasi-mechanical pattern between modern security-talk and typical responses to it, ${ }^{20}$ the main purpose of critical security studies should be to cultivate better ways of discussing the future and dangers that may lie in the future.

\section{$\underline{\text { Avoiding future dangers in terms of structural transformations }}$}

The modern probability calculus and related forms of insurance and security are constitutive of the prevailing geo-historical modes of responsiveness. A causally efficacious intervention shaping those background meanings and related modes of responsiveness may undo, and thus absent, the social mechanism of securitization. It should be stressed, however, that modern security-talk is not the only possible path towards de-democratisation, militarisation or potentially violent conflicts. ${ }^{21}$

Critical security studies can do more than avoid reification and provide a dialectical comment on the geo-historical constitution of securitization. ${ }^{22}$ The reproduction or transformation of the conditions of social action presupposes manifold and layered social structures and implies power as transformative capacity. The term "social structure" refers to internal and external relations of a positioned practice. As social scientists, we are not only interested in internal but also external social relations; not only in constitution but also in causation.

Thus what matters - apart from the framings and narratives available to an organization given the formative context - are the concrete mechanisms of choice, which select and frame issues and amalgamate stories about possible and likely futures. This is what the sociological approach to ST is good at. It can shed light on how securitization is shaped by the speaker's authority and his or her causally relevant audiences; on how particular contextual circumstances can trigger or reinforce securitization and render the relevant audience more sensitive to its vulnerability; and how securitization can occur in various fields of struggles. ${ }^{23}$

What is lacking in all forms of ST, however, is an account how the relevant contextual circumstances and structural relations of power stem from the dynamics of global political economy. Characteristically, the contextual circumstances that may trigger or reinforce securitization and render relevant audiences more sensitive to their vulnerability have to do with economic growth, levels and terms of (un)employment, socio-economic uncertainty, distribution of income, and effects of commodification. The lack of adequate politico-economic responses may even result in a spiral of downward developments involving escalation of conflicts and, potentially, war. 
Asymmetrical relations of power can shape and generate securitization. For instance, actors positioned in the practices of corporations, political parties and states may be intra- or trans-related for instance through simultaneous or successive positioning of individual actors; or interrelated through relations of financial (inter)dependency; or both, also through systems of industrial and technological planning. These kinds of power-relations condition the selection and framing of issues on the agenda, possibly involving securitization. Another example is the possibility that international financial institutes or the structural power of transnational capital constrains states' economic policies in counterproductive ways, thereby making large segments of relevant audiences in many countries more sensitive to their vulnerability.

Moreover, under circumstances characterised by a continuing and possibly deepening downward trend in the world economy, unfavourable terms of trade, financial crises, as well as population growth and environmental problems, several states may 'fail' or collapse. Thus, because of global political economy developments, wars fought in the global south may expand and/or become more frequent.

These kinds of insights have long been known to various Liberal, Keynesian and Marxian political economists. Many of them have advocated structural and institutional changes in line with their theoretical understandings, such as more democratic state structures and open world economy; more capable, fair and democratic regimes of co-operation and systems of global governance; and institutional arrangements that would enable going beyond the possibilities and constraints set by contemporary liberal-capitalist world economy. ${ }^{24}$

\section{Conclusion}

The theory of securitization has only limited explanatory power, even assuming continuity of the formative background. It can be helpful in analysing some aspects of processes that are relevant to understanding the social conditions of peace, conflict and security, but it has little to say about wider geo-historical processes. In other words, securitization theory (ST) is no more than an ideal-typical model of a particular and limited-scale social mechanism. It can do significant explanatory work only in the context of wider geo-historical theories and explanations.

From an Alkerian perspective ${ }^{25}$ ST can usefully be read as an attempt to uncover the practical grammars and deeper conceptual logic of action making particular outcomes possible. ${ }^{26}$ These logics - constituted by modern concepts of probability and risk - can be changed. They are debatable and re-negotiable. By revising the concept of probability and by introducing critical reflexivity to scenario-building, it is possible to provide better means for discussing future dangers.

In other words, ST encourages one to be critically reflexive about one's anticipations about the future and how they are used in actions and practices. While future 
dangers and their likelihood can be assessed intersubjectively, they may also be cogenerated by grammars and meanings internal to modern security practices. In particular, modern probability theory tends to be a rather misleading basis for reasonable probability-estimates about future possibilities. There are no noncontextual and stable frequencies, which could provide the basis for an 'objective' probability. The more unique the relevant historical trajectories are, the more uncertainty tends to prevail. Under uncertainty, learning more about the overall complex situation and about the relevant factors can mean that the weight of evidence and our confidence in the original probability estimate in fact decreases. The crux of this line of ethico-political argumentation can be summarized as a rule of action: the more ignorant we are about the likely consequences of our own actions, the more we should stress the role of generalizable virtues and norms and avoid undue securitization, because securitization tends to imply secrecy, violation of legitimate norms and procedures, and thus de-democratization. A process of interacting securitizations can also create enemies and make war conceivable.

It is possible to shape the circumstances and structural conditions of action, including those structural conditions and asymmetric relations of power that can make undue securitization easier. In this paper, I have especially emphasised the importance of global political economy processes in co-determining the potential for securitization as well as for opening other possible paths towards de-democratisation, militarisation or potentially violent conflicts. Unwanted sources of causal determination can be absented through structural and institutional changes, even though transformations tend to have unintended consequence too. That is, also changes towards more functional and legitimate systems of governance or government require rational knowledge about possible and likely futures.

\section{Endnotes}

\footnotetext{
${ }^{1}$ Ole Wæver, 'Securitization and Desecuritization', in Ronnie D. Lipschutz (ed.), On Security (New York: Columbia University Press, 1995), pp.46-86; Barry Buzan, Ole Wæver and Jaap de Wilde, Security: A New Framework for Analysis (Boulder CO.: Lynne Rienner, 1998).

${ }^{2}$ Thi erry Balzaq calls these two variants as philosophical and sociological in 'A Theory of Securitization: Origins, Core Assumptions, and Variants' in Thierry Balzacq (ed.), Securitization Theory. How Security Problems Emerge and Dissolve (London: Routledge, 2011), pp. 1-30; see also Holger Stritzel, 'Towards a Theory of Securitization: Copenhagen School and Beyond', European Journal of International Relations, 13:3 (2007), pp. 357-83.

${ }^{3}$ This was the original starting point of Ole Wæver, 'Security, the Speech Act: Analyzing the Politics of a Word', Working Paper 19, (Copenhagen: Center for Peace and Conflict Research, 1989). Post-structural ist ST continues to be practiced and extended to new directions by many, e..g. Jef Huysmans, 'What's in an Act? On Security Speech Acts and Little Security Nothings', Security Dialogue, 42:4-5 (2011), pp.371-383.

${ }^{4}$ For instance, Thierry Balzacq, 'The "Essence" of Securitization: Theory, Ideal Type, and a Sociological Science of Security', Review of International Studies, in this issue.
} 
${ }^{5}$ For instance, Buzan, Wæver and de Wilde, Security, on p.19 the authors merely talk about making the "constructivist deviation from objectivist, material realism [...] more sophisticated"; but on p.24 it is claimed that "security" is a self-referential practice" and on p.26 that "the task is not to assess some objective threats that 'really' endanger some object to be defended or secured".

${ }^{6}$ There are passages, however, that seem cl oser to tra ditional forms of materialist political realism. For instance, on p.51, their claim is merely that "there is no absolute correlati on between the existence of external military capability and its securitization", implying (i) that there is at least some correlation between the two and (ii) that external militaryca pabilities a re real. The a uthors express similar a mbivalence for instance a bout gl obal environmental problems and whether they are merely referent objects of securitisation or also real and a cause of concern in their own right (e.g. p.76, p.83). What is more, on pp.189-90 they seem to suggest that TS itself can help in "finding the turning points that might decide the ways in which the future will unfold".

7 Barry Buzan and Ole Wæver, 'Macrosecuritization and Security Constellations: Reconsidering Scale in Securitization Theory', Review of International Studies 35:2 (2009), p.256.

8 I owe this formulation to a draft of Stefano Guzzini's 'Securitization as a Causal Mechanism', Security Dialogue, 42:4-5 (2011), pp. 329-341; this formulation was deleted from the final version.

${ }^{9}$ Ole Wæver, 'Peace and Security. Two Concepts and Their Rel ationship' in Stefano Guzzini and Dietrich Jung (eds.): Contemporary Security Analysis and Copenhagen Peace Research (London: Routledge, 2004), p. 55.

${ }^{10}$ The concept of mathematical probability emerged in the $1660 \mathrm{~s}$, and in the first deca des its practical use was confined to certain a reas of s ta te annuities and private finance. The term "security" seems to have become increa singly associated with the field of inter-state relations and external policies of the sta tes in the $18^{\text {th }}$ and particularlyin the $19^{\text {th }}$ century, although its use remained relativelys poradic until the First World War. ${ }^{11}$ Ian Hacking, The Emergence of Probability ( $2^{\text {nd }}$ edition, Cambridge: Cambridge University Press, 2006).

${ }^{12}$ Roy Bhaskar, Dialectic. The Pulse of Freedom (London: Verso, 1993), pp. 142-44.

13 John Maynard Keynes, A Treatise on Probability (London: Rough Draft Printing/MacMillan, 2008/1920).

${ }^{14}$ This aspect the Keynesian theory is nicely spelled out in Marco Crocco, 'The Concept of Degrees of Uncertainty in Keynes, Shackle and Davidson', Nova Economia Bela Horizonte, 12:2 (2002), pp.11-27.

${ }^{15}$ Donald Gillies, 'Probability and Uncertainty in Keynes's The General Theory', in Jochen Runde \& Sohei Mizuhara (eds): The Philosophy of Keynes's Economics (London: Routledge, 2003), pp.111-29.

${ }^{16}$ See Nicholas Rescher, Dialectics. A Controversy-Oriented Approach to the Theory of Knowledge (New York: State University of New York Press, 1977).

${ }^{17}$ Heikki Patomäki, 'Exploring Possible, Likely and Desirable Global Futures: Beyond the Closed vs. Open Systems Dichotomy', in J.Joseph \& C.Wight (eds): Scientific Realism and International Relations (Palgrave: London, 2010), pp. 147-166.

${ }^{18}$ See Heikki Patomäki, The Political Economy of Global Security. Wars, Future Crises and Changes in Global Governance (London: Routledge, 2008): ch 2 'Learning from possible futures', pp. 17-35.

${ }^{19}$ David Patrick Houghton, 'The Role of Self-Fulfilling and Self-Negating Prophecies in International Relations', International Studies Review, 11:3 (2009), pp. 552-84.

${ }^{20}$ In fact, militarized national security response is only a standard possibility. Any future risk, including war and climate change, can be insured against, and these insurances can then be reinsured and (depending on financial market regulations) securitized in financial markets. On the other hand, insurances can also be made social or collective and thus obligatory, excluding private reinsurance and financial securitization.

${ }^{21}$ An open question is whether the real power and dramatic effects of securitization stem from the underlying moral na rratives more than from a mere technical risk-analysis. For an a nalysis of how US foreign policy is in important part constituted by Manichean myths and rituals of enemy-construction, see Hei kki Patomäki, 'Kosovo and the End of the UN?', in Peter Van Ham \& Sergei Medvedev (eds.): Mapping European Security After Kosovo (Manchester University Press: Manchester, 2002), pp.82-106.

${ }^{22}$ Reification means that effects of social processes are represented as being outs ide the reach of human influence, which is a key point of ST criticism against positivist security studies. The dialectical comment made by ST has involved revealing the inner logic of modern security-talk and problematising it, thus suggesting a dialectical movement forward without, however, transcending it by providing alternatives.

${ }^{23}$ Balcacq, 'A Theory of Securitization', pp. 11-15. 
${ }^{24}$ Since Immanuel Kant's Perpetual Peace, the idea of harmony of interests in free markets - free trade - has been taken as providing a generator, guarantee and strategy of peace. However, Keynesian and Marxian theorists have argued that in the liberal-capitalist world economy there are various mechanisms that generate, through unintended consequences of manifold actions, economic problems and crises that may lead to counterproductive or even aggressive international responses. For an overview of different theories, see Heikki Patomäki, 'Political Economy of International Security', in Pinar Bilgin \& Paul D. Williams (eds.) Global Security and International Political Economy. Volume 1: Global Security (Paris \& Isle of Man: UNESCO, with EOLSS Publishers, 2010), pp. 306-338; and for an excellent account of Keynes' understanding of the conditions of war and peace, Donald Markwell, John Maynard Keynes and International Relations. Economic Paths to Peace (Oxford: Oxford University Press, 2006).

${ }^{25}$ For instance, Renee Marlin-Bennett (ed.), Alker and IR: Global Studies in an Interconnected World (London: Routledge, 2011).

${ }^{26}$ See Hayward Alker, Rediscoveries and Reformulations. Humanistic Methodologies for International Studies (Cambridge: Cambridge University Press, 1996), es pecially chs 5 and 10. 